Lichenologist, 10: 101-103 (1978)

\title{
OBITUARY
}

\section{GEOFFREY CHARLES BRATT 1931-1977}

On 16 October 1977 Australian lichenology suffered a major loss in the death of Dr Geoffrey Charles Bratt. For many years he collected and studied the lichen flora of Tasmania, distributing duplicates of his collections to Australian and overseas institutions.

Geoff was born in Hobart, Tasmania, on 8 January 1931. He qualified for his Bachelor of Science degree in applied chemistry (with honours) at the University of Tasmania in 1952.

He joined the Electrolytic Zinc Corporation in January 1952 and worked in their research laboratories for 3 years. He resigned from the company in March 1955 to enroll at the Imperial College of Science, University of London, as a Ph.D. candidate.

- Geoff's life-long interest in bushwalking and climbing led him to join the 1957-58 Imperial College Exploring Society Karakorum Expedition. The aim of this expedition was to climb $\mathrm{K} 2$, the world's second highest peak. This aim was not fulfilled as time was lost on the march in, however they did climb K10. At this time Geoff was a member of the British Glaciological Society and his interest in this discipline prompted him to accept Eric Shipton's invitation to join his forthcoming expedition to Patagonia in 1958-59. It was on this expedition that Geoff met Peter James and from that time on his interest in lichens developed. In mid1959 he returned to South America, this time as leader of the Imperial College Exploration Society expedition to Apollo Bamba in the Peruvian Andes.

In 1959 he gained his doctorate and in November returned to Australia to rejoin Electrolytic Zinc Corporation as a research chemist, and at the time of his death was Senior Principle Research Officer in the Risdon Research Department. His work has primarily been on physical chemical studies of the purification and electro-deposition stages of zinc production.

Once settled back in Australia he immediately started investigating the lichen flora of Tasmania. He incorporated a work room and herbarium into the large house which he and his wife, Margaret, built in West Moonah. He collected extensively on his many bushwalking trips throughout the remote parts of the state.

In 1959 Geoff become a fellow of the Royal Geographical Society and in 1965 he received life membership of the Royal Society of Tasmania. On 29 May 1969 he was appointed Honorary Research Associate in the Department of Botany at the University of Tasmania and in this capacity he curated the Tasmanian Lichen Herbarium.

In February-March 1971 Geoff was invited to join the U.S.N. Eltanin on an expedition to Kerguelen Island in the south-west Indian Ocean to study lichens. All of his collections from this expedition were returned to the Michigan State University for determination. 
As a result of research into hydrometallurgical procedures to extract lead from zinc plant residues, he shared with $\mathrm{Dr}$ R. W. Pickering the 1971 Hofmann Prize for extractive metallurgy presented at the International Lead Conference in Hamburg, West Germany.

In 1974 he suffered a complete kidney collapse and although this prevented him from further extensive field trips it enabled him to spend more time on his collections and his major publications on lichens have been written since then.

Several new lichen species have been based on Geoff Bratt's collections, but only one, Parmelia brattii collected on Mt Roy in the South Island of New Zealand, bears his name. His lichen collection has been bequeathed to the Tasmanian Herbarium (HO).

\section{Papers of G. C. Bratt}

(1950) (with R. M. Barrer) Nonstoichiometric hydrates. I. Sorption equilibrinums and kinetics of water loss for ion-exchanged near faujasites. Physics Chem. Solids 12: 130-145.

(1953) Beyond Hell's gates. Skyline 4: 38-40.

(1954) The thick end of the wedge. Skyline 5: 48-50.

(1956) Adventure in Spain. Skyline 7: 46-48.

(1959) (with R. M. Barrer) Nonstoichiometric hydrates. II. Heats and entropies for water and ammonia in ion-exchanged faujasites. Physics Chem. Solids 12: 146-153.

(1960) Patagonian peak. Skyline 10: 10-13.

(1960) (with R. M. Barrer) Nonstoichiometric hydrates. III. The relative importance of cations and of anionic framework in determining the energetics of zeolite water. Physics Chem. Solids 12: 154-166.

(1963) (with W. N. Smith) The effects of strontium compounds and related materials in the electrolytic production of zinc. Proc. Australian Conference on Electrochemistry: 939-952.

(1964) Impurity effects in the electrowinning of zinc and cadmium. Electrochemical Technology 2 (11-12): 323-326.

(1965) (with R. B. Davies) Control of stress corrosion cracking in Monel. Australas. Corrosion Engineering 9 (8): 9-14.

(1966) Effect of pH on ion adsorption. Am. Water Works Assoc. J. 58 (2): 264-266.

(1967) Lichens in Tasmania. Tasm. Nat. 11: 1-2.

(1967) (with A. R. Gordon) Solution purification for the electrolytic production of zinc. Iń Research in Chemical and Extraction Metallurgy. A.I.M.M. (Proceedings of Symposium held in Sydney, 24-26 February 1965).

(1968) (with A. R. Ault) Electrodeposition of lead from aqueous ammoniacal ammonium sulphate solutions. Presented at Australian Conference of Electrochemistry, Melbourne, 19-23 February 1968.

(1970) (with R. W. Pickering) Production of lead via ammoniacal ammonium sulphate leaching. Metallurgical Transactions 1: 2141-2149.

(1971) Des Iles Kerguelen. Tasm. Nat. 26: 2-4.

(1972) Ecology of Tasmanian lichens. Tasm. Nat. 29: 1-4.

(1973) (with A. J. Blackman and J. A. Cashin) Distribution and chemistry of Heterodea muelleri (Hampe) Nyl. Bryologist 76: 410-413.

(1974) (with A. J. Blackman and J. A. Cashin) Umbilicariaceae in Tasmania. Lichenologist 6: 112-114.

(1975) Methods of treatment of McArthur River mixed concentrate. A.I.M.M. Proceedings 253: 3-14.

(1975) (with A. R. Ault) Control of manganese level in an electrolytic zinc plant circuit by anodic deposition of oxide. A.I.M.M. Proceedings 254: 37-45.

(1976) Lichens of South-west Tasmania Part I-Lichens of the Button grass areas. Tasm. Nat. 45: $1-4$.

(1976) Lichens of South-west Tasmania Part II-Mountain peaks and plateaux. Tasm. Nat. 46: $1-4$.

(1976) Lichens of South-west Tasmania Part III-Forests. Tasm. Nat. 47: 1-4. 
(1976) Lichens of the Cradle Mountain Area. Tasm. Tramp. 22 : 111-118.

(1977) (with A. M. Moscal) Towards a flora of Maatsuyker Island, Part 1-Introduction and vascular plants. Tasm. Nat. $5 \mathbf{1}: 14-18$.

(1976) (with A. J. Blackman and J. A. Cashin) The genus Anzia in Tasmania. Lichenologist 8: 69-77.

(1976) (with O. M. G. Newman) Use of aluminium as a cementant. Research Disclosure 147: 66-69.

(1976) (with O. M. G. Newman) Precipitation of mercury from effluents using aluminium. Presented at R.A.C.I. 4th Electrochemistry Conference, Flinders University of South Australia, 16-20 February 1976.

(1976) (with I. M. Lamb and D. J. Galloway) Two new species of Stereocaulon from New Zealand and Tasmania. Lichenologist 8: 61-67.

(1977) A view of zinc electrowinning theory. Presented at A.I.M.M. Conference, Tasmania, May 1977.

(1977) (with O. M. G. Newman, D. R. Langlois and T. R. Horsham) Precipitation of mercury from process liquors with aluminium. Presented at A.I.M.M. Conference, Tasmania, May 1977.

\section{Patents of G. C. Bratt}

(1968) (with A. R. Ault) Electrodeposition of lead and lead dioxide. Australian patent 407,231.

(1968) (with R. J. Sinclair) Improvements in or relating to the treatment of materials containing lead sulphide. Australian patent 407,232.

(1969) (with D. W. Brown) Improvements relating to the recovery of lead values from solution. Australian patent 407,999.

(1971) (with T. R. Scott and M. P. Riihela) Recovery of lead and silver from solution as sulphides. Australian patent 427,391.

(1971) Preparation of lead compounds. Australian patent 428,289.

(1973) (with O. M. G. Newman) Removal of mercury from liquors. Australian patent 449,242 .

(1974) (with O. M. G. Newman) Control of the mercury content of sulphuric acid. Australian patent 466,003 .

R. B. Filson 
